\title{
Study of the Relationship between the Sustainable Growing Social Responsibility and EVA Performance Evaluation System of Chinese Central Enterprises
}

\author{
Ting Song, Hui Peng \\ School of Management, Guangdong University of Technology, Guangzhou, China \\ Email: 1326938849@qq.com
}

Received 26 March 2015; accepted 21 April 2015; published 28 April 2015

Copyright (C) 2015 by authors and Scientific Research Publishing Inc.

This work is licensed under the Creative Commons Attribution International License (CC BY). http://creativecommons.org/licenses/by/4.0/

\section{(c) (1) Open Access}

\begin{abstract}
Under the background of Chinese central enterprises fully implementing EVA performance evaluation system, this paper takes the 231 Chinese central enterprises holdings listing corporation as a sample, building the relationship model between the sustainable growing social responsibility and EVA performance evaluation system. The study finds that central listing companies performing on the responsibility of government, shareholders, employees, society have active influence on EVA performance system, performing on the responsibility of customers, equity balance degree, enterprise scale and age have negative influence on EVA performance system while the relationship between creditors and suppliers and EVA performance system has not clear yet. We suggest that Chinese central enterprises should combine EVA and MVA into their EVA performance evaluation system in order to build their unique performance evaluation system and provide solid foundation for reference.
\end{abstract}

\section{Keywords}

Chinese Central Enterprises, Sustainable Growing, Social Responsibility, EVA Performance Evaluation System, Relationship

\section{Introduction}

Chinese central enterprises play a leading role in the national economy and have important mission for efficient operation of national economy. As benchmarking enterprises, central enterprises represent the interests of the 
state and people. Its status and nature decide that it must take the lead in fulfilling social responsibility to give full play to the demonstration effect, guide the majority of enterprises to uphold the spirit of social responsibility strategy of the SASAC of the State Council in three steps, so as to establish and improve the social responsibility management system of central enterprises. Even though many listing corporations all release social responsibility reports or sustainable development reports, the social public have greater focus and higher expectation value on the fulfilling situation of social responsibility of the central enterprises.

\subsection{Central Enterprises Social Responsibility and Sustainable Growing Target}

Fulfilling the social responsibility should be based on the economic basis, so the state should fulfill the social responsibility on the basis of considering the sustainable growing [1]. For the central enterprises, the realization of state-owned assets in order to achieve sustainable growth increment is the ultimate goal. Enterprise's sustainable growing is a kind of enterprises survival state, which is beyond insufficient or excessive growth of firms, beyond the resources and environmental constraints and beyond the product life cycle [2]. The financial thoughts are the actual growth rate of enterprises must be consistent with its own resources. In current, on the economic responsibility as the starting point of the performance evaluation system has been difficult to adapt to the demand of the state-owned enterprises achieving sustainable growing. So the construction of a set of central enterprises which is related to the interests of all parties, the financial performance and sustainable growing as the starting point of the performing evaluation system is really necessary.

\subsection{Central Enterprises Special Performance Evaluation System-EVA Performance System}

This paper argues that EVA performance system include two key performance indicators: Economic Value Added and Market Value Added. The SASAC of the State Council included the Economic Value Added (EVA) index into the performance evaluation system of state-owned enterprises since 2010 to emphasize value management. The main purpose is to maximize the value of capital as the guide, to establish a scientific and reasonable performance evaluation system and to bring it in line with international market. Since the capital market in China is still in weak type of effective state, the MVA index has not been widely used in the state. Economic Value Added (EVA) is deducted from net operating profit after tax, including the difference between the equity and all the cost of capital, is the difference between the company's capital and the cost of capital [3]. Market Value Added (MVA) is a kind of performance standards based on the market, is the difference between the enterprise market value (the value of debt and equity value) and the total investing capital of enterprises [4]. The two key indicators of EVA performance system show that the process of sustainable growing in the central enterprises, the pursuit of value should be a creative sustainable growing rather than simple growing of total value.

\subsection{Review of the Research on the Relationship between Social Responsibility and Financial Performance}

This is a hot issue about the relationship between corporate social responsibility and financial performance, the domestic and foreign scholars have conducted a lot of research. But because of the different measure, sample and research methods they have used in the sample data, there has not been a universal test results are obtained. Theory widely held the following three views: one point is the positive correlation between social responsibility and financial performance. Such as Zhang Wenbao (2010) selected 2007-2008 424 companies as the samples, found that corporate financial performance and social responsibility has significant positive correction. The second point is the correlation between social responsibility and financial performance is not significant. Mc Williams and Siegel (2000) used DSI400 (also called KLD) as the evaluation index of corporate social performance study validates the conclusion. The third point is the negative correlation between social responsibility and financial performance. Such as Li Zheng (2006) used Shanghai stock market in 2003521 listing corporation as a sample and used content analysis method to measure social responsibility, founding that the more social responsibility enterprises undertake, the lower its value [5]. Nevertheless, starting from the particularity of China's central enterprises status and nature of its performance evaluation system, sustainable growing based on the perspective of considering the study of the relationship between enterprises social responsibility and financial performance is very few. The paper mainly studies this proposition. 


\section{Hypothesis Test and Analysis Results}

\subsection{Sample Selection and Data Sources}

The paper selected samples from 2008 to 2013 in Shanghai and Shenzhen A-share market in the state holding listed companies. According to the SASAC disclosure of state holding companies listing in 2013, we found 231 state holding listed companies which is cut out of 10 data missing companies and 7 ST companies from 248 central enterprises holding listed companies. The dependent variable EVAR and MVAR were made by author via consulting and calculating relevant indicators. The financial data such as relevant independent variables and control variables were downloaded from Guotaian CSMAR database and securities website.

\subsection{EVA Calculating Model}

EVA is the balance of net operating profit after tax deducting the cost of capital.

Economic value added $=$ EVA $=$ net operating profit after tax - the cost of capital $=$ net operating profit after tax-adjusted capital $\times$ weighted average cost of capital Net operating profit after tax $=$ net profit after tax + interest expense + minority shareholders gains and losses + this year's goodwill amortization deferred tax credit balances + other reserve balances increases + capitalized research and development costs-research and development costs capitalization in the amortize Adjusted capital = the average of owns equity + the average liabilities the average non-interest current liabilities-average in progress. Weighted average cost of capital = unit equity capital cost + debt capital cost.

\subsection{Variable Description}

\subsubsection{Dependent Variable}

Variables and their definitions are described in Table 1. EVA is the absolute number and can't overcome the differences in scale. So using the average Rate of Economic Value Added (EVAR) is more scientific, Market Value Added vice versa. Rate of Economic Value Added (EVAR) reflects the ability of the company to use all assets to create value for shareholders. Rate of Market Value Added (MVAR) reflects the company uses all assets to create value increment in the market [6].

\subsubsection{Independent Variables and Research Hypothesis}

1) Sustainable growing. The fundamental goal of sustainable growing is an inexhaustible motive force for central enterprises to fulfill their social responsibility and it will promote enterprise value. Hypothesis 1: Rate of sustainable growing was positively correlated with EVA performance system;

2) Government. Central enterprises fulfill social responsibility and can get support from the government;

3) Shareholders. The primary task of central enterprises to fulfill social responsibility is to safeguard the interests of shareholders [7];

4) Creditors. Central enterprises fulfilling social responsibility is conductive to reducing the risk of creditors;

5) Suppliers. Central enterprises fulfilling social responsibility is conductive to obtaining the trust of suppliers;

6) Customers. Central enterprises fulfilling social responsibility can make customers satisfied;

7) Staff. Central enterprises fulfilling social responsibility can make the staff work hard;

8) Society. Central enterprises fulfilling social responsibility is conductive to the long-term development of enterprises.

In fact, central enterprises fulfilling social responsibility not only can fully enhance image and reputation, but also be helpful to expanding market share. Central enterprises can save hidden costs, increase the dominant income and have positive influence on EVA performance system through the different dimensions of stockholders [8].

Hypothesis 2: Social responsibility based on sustainable growing was positively correlated with Rate of EVA.

Hypothesis 3: Social responsibility based on sustainable growing was positively correlated with Rate of MVA.

\subsubsection{Control Variables}

Control Variables chosen the following index: Enterprise scale (INA), Enterprise age (AGE), Average size of the board of supervisors (JIANSHI), Average proportion of independent directors (DUDONG), Average equity balance degree (Z). 
Table 1. Variables and definitions.

\begin{tabular}{|c|c|c|c|c|}
\hline \multicolumn{2}{|c|}{ Variable types } & Variable name & Symbol & Definition \\
\hline \multirow{5}{*}{$\begin{array}{l}\text { Dependent } \\
\text { variable }\end{array}$} & EVA & Average Rate of EVA & EVAR & Average EVA/Average total assets \\
\hline & system & Average Rate of MVA & MVAR & Average MVA/Average total assets \\
\hline & $\begin{array}{l}\text { Sustainable } \\
\text { growing }\end{array}$ & $\begin{array}{c}\text { Average Rate of } \\
\text { sustainable growing }\end{array}$ & SGR & $\begin{array}{l}\text { Average equity growth ratio = Average retained } \\
\text { earnings/Initial rights and interests }\end{array}$ \\
\hline & Government & $\begin{array}{l}\text { Average contribution } \\
\text { Rate of government }\end{array}$ & GOVR & $\begin{array}{c}\text { Average } \\
\text { (tax payment-tax refund received)/Average revenue }\end{array}$ \\
\hline & Shareholders & $\begin{array}{l}\text { Average net assets } \\
\text { per share }\end{array}$ & HOLDER & $\begin{array}{l}\text { Average total stockholders’ } \\
\text { equity/Average number of ordinary shares }\end{array}$ \\
\hline \multirow{7}{*}{$\begin{array}{l}\text { Independent } \\
\text { variable }\end{array}$} & Creditors & $\begin{array}{l}\text { Average contribution } \\
\text { Rate of creditors }\end{array}$ & CRER & Average total assets/Average total debts \\
\hline & Suppliers & $\begin{array}{l}\text { Average contribution } \\
\text { Rate of suppliers }\end{array}$ & SUPR & $\begin{array}{l}\text { Average purchase goods, } \\
\text { service paid in cash/Average revenue }\end{array}$ \\
\hline & Customers & $\begin{array}{l}\text { Average contribution rate of } \\
\text { customers }\end{array}$ & CONR & Average operating costs/Average revenue \\
\hline & Staff & $\begin{array}{l}\text { Average contribution } \\
\quad \text { rate of staff }\end{array}$ & STAR & Average employee salary payable/Average total assets \\
\hline & Society & $\begin{array}{l}\text { Average social } \\
\text { contribution value per share }\end{array}$ & SOC & $\begin{array}{l}\text { No disclosure is calculated at zero, disclosed is calculated } \\
\text { according to the average of actual number }\end{array}$ \\
\hline & & Enterprise scale & INA & Natural logarithm of the average of total assets \\
\hline & & Enterprise age & AGE & $\begin{array}{l}\text { The number of the enterprises from its } \\
\text { listing date until December 31, } 2013\end{array}$ \\
\hline \multirow{3}{*}{\multicolumn{2}{|c|}{ Control variable }} & $\begin{array}{l}\text { Average size of the } \\
\text { board of supervisors }\end{array}$ & JIANSHI & Average number of supervisors \\
\hline & & $\begin{array}{l}\text { Average proportion of } \\
\text { independent directors }\end{array}$ & DUDONG & $\begin{array}{c}\text { Average number of independent directors/The number of } \\
\text { board of directors }\end{array}$ \\
\hline & & Average equity balance degree & $\mathrm{Z}$ & $\begin{array}{c}\text { The sum of shareholder's stake from } 2^{\text {nd }} \text { to } 5^{\text {th }} / \text { Average } \\
\text { proportion of the } 1^{\text {st }} \text { shareholder }\end{array}$ \\
\hline
\end{tabular}

\section{Data Analysis}

\subsection{Description Statistics}

Table 2 showed that the 231 central enterprises listing corporation EVAR mean value was $-0.76 \%$, lower than all listing corporation EVAR mean value $0.5981 \%$ of the same period. It indicated that state-owned enterprises generally have problems of high capital costs or much nonrecurring profit. The mean MVAR was $90.83 \%$; mean SGR was 9.13\%. This showed that most of the sample enterprises have the advantage of future sustainable growing and higher market value. Overall, the sample average contribution rate of government was 5.84\%; the average net assets per share were 3.89 which mean larger contribution to shareholders. The average rate of asset-liability ratio (the reciprocal of the contribution rate of creditors) was 53.29\%, below the National Evaluation Board approving the upper limit of $60 \%$. It showed central enterprises fulfilling better social responsibility to creditors. The average contribution rate of suppliers was $72.62 \%$; the average contribution rate of customers was 79.15\%, the proportion was rather large which indicated that central enterprises generally pay more attention their responsibility to suppliers and customers. The average contribution rate of staff was $0.94 \%$; the average contribution rate of society was $20.56 \%$, very reasonable. In the control variables, the average size of the board of supervisors was up to 4.3 people, average proportion of independent directors was 0.45 , in line with provisions pf the relevant laws of our country. The average equity balance degree was 0.40 , indicating that the higher percentage of the first shareholder, in accordance with the nature of central enterprise.

\subsection{Correlation Analysis}

From Table 3, we can know: 1) EVAR, MVAR, SGR have significantly positive influence on each other. SGR 
Table 2. Description statistics.

\begin{tabular}{cccccccccccc}
\hline & Min & Max & Mean & $\begin{array}{c}\text { Standard } \\
\text { deviation }\end{array}$ & & Min & Max & Mean & $\begin{array}{c}\text { Standard } \\
\text { deviation }\end{array}$ & N \\
\hline EVAR & --0.1405 & 0.1311 & -0.007607 & 0.0410050 & STAR & 0.0001 & 0.0545 & 0.009360 & 0.0092951 & 231 \\
MVAR & -0.0907 & 4.8891 & 0.908303 & 0.7363219 & SOC & 0.00 & 5.94 & 0.2056 & 0.73907 & 231 \\
SGR & -0.0038 & 1.4172 & 0.091282 & 0.1072078 & INA & 19.99 & 28.21 & 22.8667 & 1.60057 & 231 \\
GOVR & -0.0657 & 0.6857 & 0.058399 & 0.0678293 & AGE & 2.00 & 22.00 & 13.1212 & 5.07792 & 231 \\
HOLDER & 0.2525 & 20.0050 & 3.89036 & 2.08743 & JIANSHI & 2.60 & 9.25 & 4.2965 & 1.43905 & 231 \\
CRER & 1.0523 & 17.5031 & 1.8765 & 1.7863377 & DUDONG & 0.19 & 0.98 & 0.4514 & 0.14141 & 231 \\
SUPR & 0.0039 & 5.1462 & 0.726200 & 0.3738504 & Z & 0.02 & 2.17 & 0.3975 & 0.37588 & 231 \\
CONR & 0.1576 & 1.2415 & 0.791547 & 0.1461831 & effective N & & & & & \\
\hline
\end{tabular}

Table 3. Correlation.

\begin{tabular}{lllllllllllll}
\hline \multicolumn{2}{c}{ Control Variables } & EVAR & MVAR & SGRe & GOVR & HOLDER & CRER & SUPR & CONR & STAR & SOC \\
\hline $\begin{array}{c}\text { INA \& AGE } \\
\text { \& JIANSHI \& } \\
\begin{array}{c}\text { DUDONG } \\
\text { \& Z }\end{array}\end{array}$ & MVAR & Correlation & 1.000 & $0.381^{* *}$ & $0.248^{* *}$ & $0.359^{* *}$ & $0.233^{* *}$ & -.054 & -.094 & $-0.498^{* *}$ & $0.181^{* *}$ & $0.165^{*}$ \\
& SGR & Correlation & $0.381^{* *}$ & 1.000 & $0.179^{* *}$ & 0.107 & 0.011 & 0.085 & 0.122 & $-0.168^{*}$ & $0.162^{*}$ & 0.090 \\
\hline
\end{tabular}

${ }^{* *}$. At 0.01 level significantly correlated (bilateral). ${ }^{*}$. At 0.05 level significantly correlated (bilateral).

indicates the developing ability of a company. EVAR and MVAR reflect company's performance and value. Essentially, all of the 3 index are measure indicators of corporate performance, hypothesis 1 certificated; 2) GOVR, HOLDER, STAR and SOC have significantly active influence on EVAR, on the opposite, CONR have significantly negative influence on EVAR. But CRER and SUPR have weak negative influence on EVAR. It indicates measured in EVAR, central enterprises implemented the responsibility of government, shareholders, staff and society can be quickly and significantly improve performance. But the responsibility to creditors and suppliers cannot accomplish at one stroke. This is because the effect of enterprises social responsibility to enterprises performance has lagged behind, unable to promote the achievement of significant growth in short term. 3) MVAR has significant positive correlation with Staff at 5\% level; MVAR has significant negative correlation with CONR. On the opposite, MVAR has weak negative correlation with GOVR, HOLDER, CRER, SUPR and SOC. It indicates measured in MVAR, the satisfaction of Staff can bring performance increasing effect, at the same time, central enterprises should make clear to fulfill the responsibility to government, shareholders, creditors, suppliers and social actively.

In general, if central enterprises can achieve the objectives of sustainable growing, it will help company to enhance its performance. There was a significant positive correlation between the responsibility of central enterprises to government, shareholders, staff, society and EVA performance evaluation system. And there was a significant negative correlation between the responsibility of central enterprises to customers and EVA performance evaluation system. But the relationship between the responsibility of central enterprises to creditors, suppliers and EVA performance evaluation system haven’t clear yet.

\subsection{Results of Regression Analysis}

Table 4 showed that the results of regression analysis were close to correlation analysis: 1) In EVAR model based on sustainable growing, EVAR have significant positive correlation with shareholders, staff, society, but have significant negative correlation with creditors, customers, equity balance degree. In further, EVAR have weak positive correlation with government, while have weak negative correlation with suppliers. 2) In MVAR model based on sustainable growing, MVAR has significant positive correlation with government, suppliers, 
Table 4. Regression model summary.

\begin{tabular}{|c|c|c|c|c|}
\hline & \multicolumn{2}{|c|}{ EVAR model } & \multicolumn{2}{|c|}{ MVAR model } \\
\hline & Standard coefficient & $\mathrm{t}$ & Standard coefficient & $\mathrm{t}$ \\
\hline (Constant) & 0.072 & 1.770 & $7.294^{* *}$ & 9.698 \\
\hline SGR & $0.046^{*}$ & 2.179 & $0.939^{*}$ & 2.406 \\
\hline GOVR & 0.077 & 1.519 & $1.913^{*}$ & 2.079 \\
\hline HOLDER & $0.003^{* *}$ & 2.839 & 0.022 & 1.07 \\
\hline CRER & $-0.004^{* *}$ & -3.214 & 0.026 & 1.061 \\
\hline SUPR & -0.003 & -.388 & $0.467^{* *}$ & 3.488 \\
\hline CONR & $-0.118^{* *}$ & -5.110 & $-1.384^{* *}$ & -3.246 \\
\hline STAR & $0.697^{* *}$ & 2.910 & $9.689^{*}$ & 2.192 \\
\hline SOC & $0.004^{*}$ & 1.445 & 0.054 & 0.958 \\
\hline INA & 0.000 & 0.139 & $-0.236^{* *}$ & -8.158 \\
\hline AGE & -0.001 & -1.933 & $-0.016^{*}$ & -2.009 \\
\hline JIANSHI & 0.000 & -0.154 & 0.051 & 1.033 \\
\hline DUDONG & 0.022 & 0.823 & -0.556 & -1.124 \\
\hline $\mathrm{Z}$ & $-0.011^{*}$ & -1.956 & -0.164 & -1.523 \\
\hline F & \multicolumn{2}{|c|}{12.114} & \multicolumn{2}{|c|}{10.606} \\
\hline Adj. $R^{2}$ & \multicolumn{2}{|c|}{0.386} & \multicolumn{2}{|c|}{0.352} \\
\hline DW & \multicolumn{2}{|c|}{ 1.843 No autocorrelation } & \multicolumn{2}{|c|}{ 1.931No autocorrelation } \\
\hline $\mathrm{VIF}_{\max }$ & \multicolumn{2}{|c|}{2.602} & \multicolumn{2}{|c|}{2.602} \\
\hline
\end{tabular}

staff, but have significant negative correlation with customers, enterprise scale and age. In further, EVAR have weak positive correlation with shareholders, creditors and society.

EVAR model included shareholders, staff, creditors, customers and society five key stakeholders, and MVAR model included government supplies two key stakeholders. The seven dimensions of stakeholders are the most widely used narrow sensed stakeholders. Therefore, the author advices that we should put EVAR model and MVAR model in combination. It can make omni-directional investigation of central enterprises to fulfill the relationship between social responsibility and corporate performance.

Robust test: Two model of F statistic value were 12.114 and 10.606, and at the $1 \%$ significant level of confidence. It means on the whole the multivariate linear regression model was reasonable. Correction R2 were 0.386 and 0.352 , total was 0.738 , shows the two regression equations can explain $73.8 \%$ of total variation, very reasonable. DW test value is close to 2, each without correlation between variables, ruling out the possibility of multicollinearity and serial correlation. In addition, the variance inflation factor VIF was 2.602; VIF was small, explaining that the possibility of collinearity lead by variables is small.

\section{Conclusions and Suggestion}

From the perspective of sustainable growing, central enterprises listing corporation fulfill their responsibility to government, shareholders, staff, society actively have positive influence on EVA performance system. But fulfilling the responsibility to customers has significant negative effect on EVA performance system, the main reason is that central enterprises give must benefits to customers, resulting in increasing short-term costs, which had a negative impact on economic benefits. But from a long-term perspective, it is helpful to creating good corporate image and forming core competence of sustainable growing. Because the inspection time is short, different indicators get inconsistent conclusions. The relationship between creditors and suppliers, the two special 
stakeholder and EVA performance system, is not yet clear.

EVA performance system is negatively related to equity balance degree (Z). It means that the smaller $\mathrm{Z}$ value is, the greater enterprise value is, which indicates present situation of central enterprise's capital structure of big state owned shares. EVA performance system is negatively related to enterprise scale and age, which indicates that central enterprises have generally entered the mature period.

So we suggest that: 1) Government should improve social responsibility of relevant laws and regulations, strengthen supervision and increase the intensity PF rewards and punishments. The implement of social responsibility should be based on laws and regulations. We should also strengthen the propaganda of social responsibility and encourage some company if they can fulfill their social responsibility very well, such as preferential tax. 2) Central enterprises should earnestly perform their social responsibilities and obligations to stakeholders, considering combine social responsibility into sustainable growing strategy. Paying taxes in accordance with the laws; making efforts to create wealth for shareholders; respect for their employees; paying attention to social public welfare and so on which can effectively promote the sustainable growing of central enterprises performance. 3) Building central enterprises EVA performance system which is combined by EVA and MVA and is based on the target of sustainable growing gradually. Central enterprises should establish the early warning for the performance evaluation system of the past and future oriented combination, in order for enterprises to fulfill their social responsibilities to strengthen the coordination of social responsibility and financial performance and to provide the basis for decisive making [9]. EVA evaluates the enterprise operating performance in the past, but MVA pays more attention to the market of business prospects and risk assessment. We suggest combining EVA and MVA into central enterprises EVA performance system, for building central enterprises' unique performance appraisal system to provide solid foundation.

\section{References}

[1] Yang, H.M. and Deng, Q.W. (2011) Study of Social Responsibility and Achievements of Chinas State-Owned Enterprises: Based on Sustainable Development Perspective. Journal of Central South University of Economics and Law, 1, 120-127.

[2] Zhou, L.B. and Yang, Q. (2014) Effect of Corporate Growth on Financial Flexibility: Empirical Evidence Based on Listed Companies in Manufacturing Industry. Journal of Central South University (Social Science), 20, 33-38.

[3] Ouyang, C.H. (2014) Study on the Adjustment of Accounting EVA. Communication of Finance and Accounting, 22, 109-112.

[4] Wang, L.N. (2010) Empirical Analysis on EVA, MVA Index Application. Finance and Accounting Monthly, 3, 43-45.

[5] Tang, L.P. and Wang, Q.S. (2011) Corporate Social Responsibility and Financial Performance of the Correlation Research Review. Friends of Accounting, 29, 23-25.

[6] Dong, S.B. (2011) Analysis of Economic Value Added Application in Enterprise Management. Finance \& Economics, 12, 158-159.

[7] Liu, L.H. (2011) On the Relationship between Corporate Social Responsibility and Corporate Financial Performance. Guangdong Social Science, 6, 100-105.

[8] Liu, J.-Q. and Song, X.-Z. (2011) Corporate Social Responsibility, CSR Communication and Corporate Value. Collected Essays on Finance and Economics, 157, 84-91.

[9] Wen, S.-B. and fang, Y. (2008) An Empirical Research on Relationship between Corporate Social Responsibility and Financial Performance-Analysis Based on Stakeholder Theory and Panel Data. China Industrial Economics, 10, 150 160. 